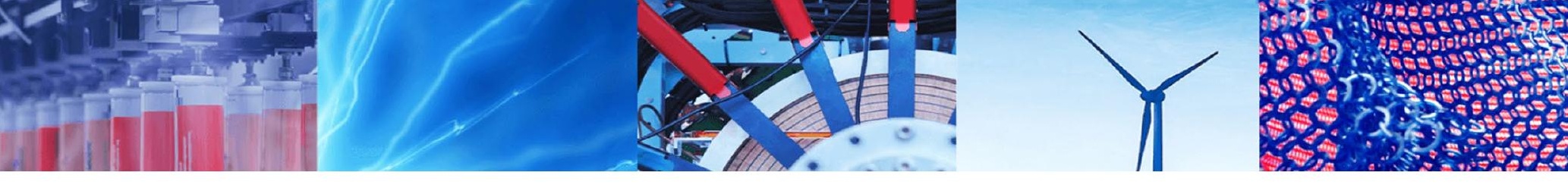

Research Article

\title{
Understanding the chemistry of manganese fertilizers and glyphosate mixtures by using synchrotron X-ray spectrometry
}

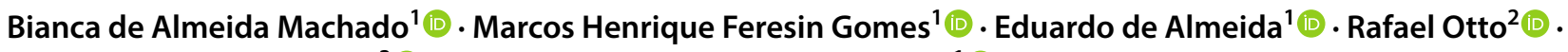 \\ Marcos Yassuo Kamogawa ${ }^{3}$ (D) Hudson Wallace Pereira de Carvalho' ${ }^{1}$
}

Received: 27 May 2020 / Accepted: 5 October 2020 / Published online: 17 October 2020

(c) Springer Nature Switzerland AG 2020

\begin{abstract}
The spraying of tank mixtures with manganese $(\mathrm{Mn})$ and glyphosate is a practical alternative to alleviate nutritional deficiency while controlling weeds. Thereby, this study investigates the chemical interactions between glyphosate and commercial sources of $\mathrm{Mn}$, such as $\mathrm{MnSO}_{4}, \mathrm{Mn}$-phosphite, $\mathrm{Mn}$-EDTA, $\mathrm{Mn}$-glycine, and $\mathrm{MnCO}_{3}$. Nearly $30 \%$ of the $\mathrm{Mn}$ supplied as $\mathrm{MnSO}_{4}$ and $\mathrm{Mn}$-glycine precipitated with glyphosate, yielding a Mn:glyphosate solid complex with molar ratio of nearly 2:1, both presenting similar chemical environment. XANES analysis of the supernatants indicate no formation of $\mathrm{Mn}$-glyphosate soluble complexes. The use of $\mathrm{Mn}$-EDTA as well as the maintenance of the mixture pH below 2.5 prevented precipitation, while $\mathrm{pH}$ above 7 caused the formation of $\mathrm{MnO}(\mathrm{OH})$. In conclusion, the $\mathrm{Mn}$ source and the $\mathrm{pH}$ of the mixtures matter. The absence of $\mathrm{Mn}$-glyphosate soluble complexes suggests that dissolved $\mathrm{Mn}$ and glyphosate are still able to accomplish their functions, however, the precipitation significantly decreases their active availability.
\end{abstract}

Keywords Tank mixture $\cdot$ Mn-glyphosate complex $\cdot$ Soybean $\cdot$ Weed control $\cdot$ XAS

\section{Introduction}

In the 2019/2020 crop season, Brazil cultivated 36 million of hectares of soybean (Glycine max L.), harvesting more than 125 million tons of grains. Such achievement made Brazil the world's largest soybean producer, a title previously belonged to the USA [1]. The increasing cultivation under no-tillage systems has caused the widespread use of lime applications in Brazil. This practice raise the topsoil $\mathrm{pH}$, decreasing availability and consequent root uptake of transition metal micronutrients, such as manganese (Mn) [2]. Manganese is required by many plant enzymes, and plays an important role in photosynthesis, nitrogen metabolism, nodulation, and respiration. It is also a component of aromatic amino acids, auxins, phenols and lignin [3]. The importance of $\mathrm{Mn}$ for plant nutrition and the current evidence of $\mathrm{Mn}$ deficiency in soybean trials increased the usage of $\mathrm{Mn}$ by soybean growers all over Brazil.

Meanwhile, the transgenic glyphosate-resistant soybean was introduce and rapidly adopted in Brazil, since it highly facilitates the weed management. Indeed, glyphosate ([N-(phosphonomethyl)glycine]) is a non-selective herbicide which mechanism of action consists of competitive inhibition of the enzyme 5-enolpyruvylshikimate3-phosphate synthase, essential for the biosynthesis of the aromatic amino acids phenylalanine, tyrosine and

Electronic supplementary material The online version of this article (https://doi.org/10.1007/s42452-020-03632-y) contains supplementary material, which is available to authorized users.

$\triangle$ Hudson Wallace Pereira de Carvalho, hudson@cena.usp.br | ${ }^{1}$ Laboratory of Nuclear Instrumentation (LIN), Center for Nuclear Energy in Agriculture (CENA), University of São Paulo (USP), Piracicaba, SP 13416-000, Brazil. ²Department of Soil Science, Luiz de Queiroz College of Agriculture, University of São Paulo (USP), Piracicaba, SP 13416-000, Brazil. ${ }^{3}$ Department of Exact Sciences, Luiz de Queiroz College of Agriculture, University of São Paulo (USP), Piracicaba, SP 13416-000, Brazil. 
tryptophan [4]. Besides the introduction of transgenic crops, glyphosate's success is also due to its highly effective broad spectrum and low toxicity for animals [5], being also a very cheap herbicide [6]. Glyphosate is considered a once in a century herbicide [5], being the best-selling active ingredient for herbicides worldwide [7]. In 2018, more than 190 thousands of tons of glyphosate's active ingredient and its salts were sold within the Brazilian territory, four times more than the second best-selling herbicide, the 2,4-D [8, 9].

In Brazilian soybean fields, Mn foliar fertilization [10] is often performed in conjunction with glyphosate at least twice during the crop cycle, generally around the V 3 and V7 phenological stages. The tank mixing is as an alternative to reduce the number of fields sprayings, farmers costs, soil compaction, and mechanical damage to the crop [11]. This practice can, however, compromise not the sole efficacy of weed control by glyphosate, but also the nutrition potential of the dissolved ions. In that respect, Bernards et al. [12] demonstrated that glyphosate interactions with $\mathrm{Mn}$ increased at higher $\mathrm{pH}$ values of the mixture similar to those found in plant symplast. It was also noticed a significant decrease of leaf $\mathrm{Mn}$ content in soybean plants, after foliar applications of glyphosate [13].

Face to the wide adoption of tank mixtures with $\mathrm{Mn}$ and glyphosate, and considering their antagonist potential on both weed control and plant nutrition, this survey targeted the chemical reactions between this herbicide and five of the most common $\mathrm{Mn}$ sources $\left(\mathrm{MnSO}_{4}, \mathrm{Mn}\right.$-EDTA, $\mathrm{Mn}$-phosphite, $\mathrm{Mn}$-glycine, and $\mathrm{MnCO}_{3}$ nanopowder). The effect of the $\mathrm{pH}$ on $\mathrm{MnSO}_{4}+$ glyphosate interactions was also evaluated. Therefore, the electric conductivity $(\mathrm{EC})$ and $\mathrm{pH}$ of the mixtures were monitored over $72 \mathrm{~h}$, while X-ray fluorescence spectroscopy (XRF) quantified the amount of glyphosate and $\mathrm{Mn}$ found in the solution and in the precipitates. Chemical speciation analysis using $X$-ray absorption near edge structure (XANES) determined the $\mathrm{Mn}$ chemical environment for both supernatants and precipitates. The chemistry of $\mathrm{MnSO}_{4}+$ glyphosate supernatants at different $\mathrm{pH}$ was evaluated through XANES. Thermogravimetric analysis revealed the composition of precipitates at $\mathrm{pH} 7$, and zeta potential and dynamic light scattering (DLS) analysis showed the charge and diameter of the precipitates' particles in a varying $\mathrm{pH}$.

\section{Materials and methods}

\subsection{Reagents and experimental design}

The following Mn sources were employed: $\mathrm{MnSO}_{4} \cdot \mathrm{H}_{2} \mathrm{O}$ (31.85 wt.\% Mn, Synth, Brazil), $\mathrm{MnCO}_{3}$ nanopowder 80-100 nm (47.78 wt.\% Mn, Nanoshel LLC, USA),
Mn-ethylenediaminetetraacetic acid (Mn-EDTA) (13 wt.\% Mn, Stoller, Brazil), $\mathrm{Mn}$-phosphite $\left(\mathrm{MnHPO}_{3}\right)$ (8 wt.\% Mn, Agrivalle, Brazil), and Mn-glycine (22 wt.\%, Stoller, Brazil). The employed Mn-EDTA, Mn-phosphite and $\mathrm{Mn}$-glycine are commercial products, while the $\mathrm{MnSO}_{4}$ and $\mathrm{MnCO}_{3}$ are lab reagents. The glyphosate employed in this study was also a commercial product $\left(\mathrm{C}_{3} \mathrm{H}_{8} \mathrm{NO}_{5} \mathrm{P}\right)$ (48 wt.\% active ingredient, 36 wt.\% acid equivalent, and $68.5 \mathrm{wt} . \%$ of inert ingredients), obtained from Ameribrás (Brazil). It worth mentioning that the real composition regarding the inert ingredients from the glyphosate source is not known. Generally, it is composed by surfactants, diluents or adjuvants which stabilize the formulation and improve the product penetration within the plants, but the real composition is considered confidential business information [14].

The experiments were carried out in triplicate using the five Mn sources, with and without glyphosate.

\subsection{Solution and dispersion preparation}

The solutions and dispersions containing $\mathrm{Mn}$, with and without glyphosate, were prepared based on the recommended field doses of $350 \mathrm{~g} \mathrm{ha}^{-1}$ of $\mathrm{Mn}$ [15] and $1.5 \mathrm{~L} \mathrm{ha}^{-1}$ of glyphosate. Considering the application of $50 \mathrm{~L} \mathrm{ha}^{-1}$ of the spray mix, the employed concentrations were $7 \mathrm{~g} \mathrm{~L}^{-1}$ of $\mathrm{Mn}$ and $30 \mathrm{~mL} \mathrm{~L}^{-1}$ of glyphosate (10.8 $\mathrm{g} \mathrm{L}^{-1}$ acid equivalent). It corresponds to a $\mathrm{Mn}$ :glyphosate molar ratio of nearly 2:1. All measurements ( $\mathrm{pH}$, electric conductivity, $\mathrm{Mn}$ fractionation, thermal analysis, $\mathrm{pH}$ assay, and XAS) were carried out in three repetitions.

\section{3 pH and electric conductivity measurements}

The $\mathrm{Mn}$ solutions/dispersion ( $25 \mathrm{~mL}$ ) were transferred to $50 \mathrm{~mL}$ plastic vials, as the $\mathrm{pH}$ and electric conductivity (EC) were measured using InLab ${ }^{\circ}$ Expert Pro-ISM and InLab ${ }^{\circ}$ 731-ISM sensors, respectively, coupled to the SG-23 SevenGo DuoTM equipment (Mettler-Toledo, Switzerland). Subsequently, glyphosate $(750 \mu \mathrm{L})$ was added in the solution/dispersion and fully homogenized by manual stirring. Immediately after, the $\mathrm{pH}$ and EC were measured. From this time on, the plastic vials were closed and left undisturbed, under room temperature and dark. $\mathrm{pH}$ and EC measurements were carried out afterwards every $4 \mathrm{~h}$ in the first $24 \mathrm{~h}$, with an extra measurement made around $72 \mathrm{~h}$ after the glyphosate addition (Figure $\mathrm{S} 1$ ). This time range covers field conditions, the first $24 \mathrm{~h}$ being the most critical period, as factually spraying solutions hardly exceeds this time limit. 


\subsection{Mn fractionation}

The Mn fractionation was determined based on Almeida et al. [16], with modifications. The fertilizers solutions and dispersions, with and without glyphosate, were prepared following the sample preparation described above (Sect. 2.2). Aliquots (7 $\mu \mathrm{L})$ of the solutions/dispersions were sampled right after the mixtures, then the samples were centrifuged for $2 \mathrm{~h}$ at $1464 \mathrm{~g}$, in order to separate any precipitate from supernatants, being the supernatants also sampled $(7 \mu \mathrm{L})$.

The $7 \mu \mathrm{L}$ aliquots were transferred into $1 \mathrm{~mL}$ plastic vials, the surfactant Triton $X-100$ solution at $5 \%(v / v)(5 \mu \mathrm{L})$, purified water $(938 \mu \mathrm{L})$, and $1003 \mathrm{mg} \mathrm{Ga} \mathrm{L}^{-1}$ internal standard $(50 \mu \mathrm{L})$ were subsequently added.

The insoluble phase of the precipitated treatments was collected and dried in a laboratory oven $\left(60^{\circ} \mathrm{C}\right)$ until reach constant mass. The precipitates were weighed, ground manually using an agate mortar, and microwave-assisted acid digested. For the latter procedure, the precipitates (20 mg) were transferred into pre-cleaned Teflon TFM tubes, mixed with $\mathrm{HNO}_{3} 20 \%(\mathrm{v} / \mathrm{v})(5 \mathrm{~mL})$ and $\mathrm{H}_{2} \mathrm{O}_{2} 30 \%$ $(\mathrm{v} / \mathrm{v})(2 \mathrm{~mL})$. So, the samples placed in the microwave oven (DGT 100 Plus, Provecto Analítica, Brazil) followed a heating treatment of $7 \mathrm{~min}$ at $400 \mathrm{~W}, 15 \mathrm{~min}$ at $850 \mathrm{~W}$ and $7 \mathrm{~min}$ at $320 \mathrm{~W}$. The final solution was transferred to $50 \mathrm{~mL}$ plastic vials and diluted up to $40 \mathrm{~mL}$ with purified water. Finally, an aliquot of the solutions $(330 \mu \mathrm{L})$ was transferred to $1 \mathrm{~mL}$ plastic vial, and the surfactant Triton X-100 solution at $5 \%$ $(\mathrm{v} / \mathrm{v})(5 \mu \mathrm{L})$, purified water $(615 \mu \mathrm{L})$, and $1003 \mathrm{mg} \mathrm{Ga} \mathrm{L}^{-1}$ internal standard $(50 \mu \mathrm{L})$ were subsequently added.

The concentration of $\mathrm{Mn}, \mathrm{P}$ and $\mathrm{S}$ in the pristine solutions and dispersions containing $\mathrm{Mn}$, with and without glyphosate, supernatants and in the precipitate (after microwave-assisted digestion) were determined by energy dispersive $\mathrm{X}$-ray fluorescence spectrometer (EDXRF, Shimadzu, EDX-720, Japan).Therefore, $10 \mu \mathrm{L}$ of each prepared sample were pipetted on the external side of the $31 \mathrm{~mm}$ diameter poly(ethylene) XRF cuvette (cat. no. 1530, Chemplex, USA) covered with $6 \mu \mathrm{m}$ thick polypropylene film (VHG Labs, USA). Then, the samples were dried in laboratory oven $\left(60^{\circ} \mathrm{C}\right)$.

The EDXRF was operated using a Rh X-ray tube at $50 \mathrm{kV}$ and applying an auto-tunable current to a $30 \%$ maximum dead time. The analysis was carried out under vacuum and using a 10-mm diameter collimator (Shimadzu, Japan) for 200 s. The X-ray spectrum was acquired by a Si(Li) detector. The quantification was carried out using external calibration (Figure S2).

Limits of detection (LOD) and quantification (LOQ) were determined as stated by Almeida et al. [16] and Kadachi and Al-Eshaikh [17], respectively, following the Eqs. (1) and (2):
$L O D=\frac{3}{l_{G a} * S} \sqrt{\frac{B G}{t}}$

$L O Q=L O D \times 3.33$

where LOD, LOQ, $S, I_{G a}, B G$ and $t$ are the limit of detection $\left(\mathrm{mg} \mathrm{L}^{-1}\right)$, limit of quantification $\left(\mathrm{mg} \mathrm{L}^{-1}\right)$ relative elemental sensitivity $\left(\mathrm{mg}^{-1} \mathrm{~L}\right), \mathrm{Ga}$ intensity (cps), background intensity (cps) of the analyte, and the acquisition time (s).

\subsection{X-ray absorption near edge structure (XANES) characterization}

XANES measurements were carried out in liquid and solid phases formed before and after the addition of glyphosate into the Mn solutions/dispersion. Glyphosate was added to the liquid samples ca. $2.5 \mathrm{~h}$ prior to the analysis, fitting to field conditions. Solid samples preparation was done according to Gomes et al. [18] with modifications. From solid samples (precipitates and $\mathrm{MnCO}_{3}$ ) previously dried in a laboratory oven at $60^{\circ} \mathrm{C}$ and diluted in cellulose at $1.5 \mathrm{Mn}$ wt.\%, were then prepared $100 \mathrm{mg}$ pellets using a $13 \mathrm{~mm}$ stainless steel die set pressed at $500 \mathrm{~kg}$ for $1 \mathrm{~min}$ (Carver 3912, USA).

The liquid samples were placed in acrylic $1 \mathrm{~mm}$ thick sample holders covered with Kapton tape (Figure S3A). Solid ones were fixed in sample holders using Kapton tape (Figure S3B).

The measurements were performed in transmission mode at the XRF beamline of the Brazilian Synchrotron Light Laboratory (LNLS). The XRF beamline is equipped with a bending-magnet, Si (111) double crystal monochromator, KB mirror system resulting in a $20 \mu \mathrm{m}$ diameter spot size. The detection was made using ionization chambers before and after the sample. The $20 \mu \mathrm{m}$ beam was positioned at the center of the samples and the XANES spectra recorded between -100 and $200 \mathrm{eV}$ across the $\mathrm{Mn}-\mathrm{K}$ edge. Three scans per sample were collected and merged to improve the signal-to-noise ratio, each measurement being replicated three times.

The spectra were merged, energy-calibrated using a Mn-foil, and then normalized using Athena software within the IFEFFIT package [19].

\section{6 pH assay: chemical speciation of $\mathrm{MnSO}_{4}+$ glyphosate solutions at different $\mathrm{pH}$}

$\mathrm{MnSO}_{4}$ solutions ( $7 \mathrm{~g} \mathrm{~L}^{-1}$ of $\mathrm{Mn}$ ) were mixed with glyphosate (10.8 $\mathrm{g} \mathrm{L}^{-1}$ of acid equivalent) and their $\mathrm{pH}$ adjusted to $1,3,5$ and 7 , adding $\mathrm{H}_{2} \mathrm{SO}_{4}$ or $\mathrm{NaOH}$. The $\mathrm{pH}$ was measured using the $\mathrm{pH}$ meter Tec-2 (Tecnal, Brazil). Subsequently, these solutions were centrifuged ( $1464 \mathrm{~g}$ ) for $2 \mathrm{~h}$, and the 
supernatants were separated from the precipitates using Pasteur pipettes.

Chemical speciation analysis of the supernatants was conducted in transmission mode also at the previously cited XRF beamline of the Brazilian Synchrotron Light Laboratory (LNLS).

\subsection{Thermal analysis (gravimetric-TGA and differential-DrTGA)}

Thermal analysis was made on the precipitates formed after increasing the $\mathrm{pH}$ of $\mathrm{MnSO}_{4}$ solutions with and without glyphosate. To prepare the samples, $\mathrm{MnSO}_{4}$ was dissolved in purified water at the concentration of $7 \mathrm{~g} \mathrm{~L}^{-1}$ of $\mathrm{Mn}$. The $\mathrm{pH}$, initially approximately 4.4 , was adjusted to 7 using $\mathrm{NaOH}$ solution. The titration was made under stirring by a magnetic mixer. A precipitate of a brownish compound was noticed due to this $\mathrm{pH}$ increase.

For $\mathrm{MnSO}_{4}+$ glyphosate samples, glyphosate $\left(10.8 \mathrm{~g} \mathrm{~L}^{-1}\right.$ of acid equivalent) was added to the $\mathrm{MnSO}_{4}$ solution at $\mathrm{pH}$ 7. The glyphosate addition causing a $\mathrm{pH}$ decrease, and $\mathrm{NaOH}$ was employed to readjust the $\mathrm{pH}$ to 7 . In this case, a lighter brownish compound precipitate was observed.

The supernatants were properly discarded after centrifuging the samples at $1464 \mathrm{~g}$ for $1 \mathrm{~h}$. The precipitates were placed into the laboratory oven $\left(50^{\circ} \mathrm{C}\right)$ until reach constant mass. After drying, the precipitates were ground manually using an agate mortar, weighted, before a thermal analysis. Each treatment was prepared trough three independent experiments.

The thermal analysis was performed by a Shimadzu DTG-60H equipment-simultaneous TG-DrTGA, from room temperature till $1100^{\circ} \mathrm{C}$ under $\mathrm{N}_{2}$ atmosphere and heating rate of $10^{\circ} \mathrm{C} \mathrm{min}^{-1}$.

\subsection{Dynamic light scattering analysis (DLS) and microelectrophoresis (zeta potential) analysis}

The DLS and zeta potential analysis were performed in $\mathrm{MnSO}_{4}+$ glyphosate solutions under several $\mathrm{pH}$ values. $\mathrm{A}$ $\mathrm{MnSO}_{4}$ stock solution was prepared at the concentration of $7 \mathrm{~g} \mathrm{~L}^{-1}$ of $\mathrm{Mn}$, which presented an initial pH of ca. 4.4, then $10 \mathrm{~mL}$ aliquots of the stock solutions were separated for the $\mathrm{pH}$ adjustments to 5 or 7 using $\mathrm{NaOH}$ solution. Later, $300 \mu \mathrm{L}$ of glyphosate were added to the aliquots, aiming a final glyphosate concentration of $10.8 \mathrm{~g} \mathrm{~L}^{-1}$ (acid equivalent). Then, the $\mathrm{pH}$ was readjusted to 5 or 7 . A treatment with no $\mathrm{pH}$ adjustment was also completed, which presented a pH of 2.5 after the glyphosate addition. The $\mathrm{Mn}$ and glyphosate concentrations used here fit to field applications [15].
The DLS and zeta potential analysis were performed using a ZetaSizer Nano ZS90 particle analyzer (Malvern Instruments). Samples at pH 2.5 and 5 had to be diluted 10 and 20-fold, respectively, due to their light scattering properties, while samples at $\mathrm{pH} 7$ did not require any dilution. Three repetitions of each treatment were evaluated.

\section{Results and discussion}

\subsection{Monitoring the $\mathrm{pH}$ and electric conductivity}

The $\mathrm{pH}$ and electric conductivity (EC) of the tank mixtures were monitored for $\mathrm{ca} .72 \mathrm{~h}$. Glyphosate addition promoted changes in $\mathrm{pH}$ and $\mathrm{EC}$ of solution/dispersion for all $\mathrm{Mn}$ sources, especially during the first $5 \mathrm{~h}$ after its addition (Fig. 1). Past $5 \mathrm{~h}$, the $\mathrm{EC}$ remained constant for all mixtures; however, for $\mathrm{MnSO}_{4}$ and $\mathrm{Mn}$-glycine, the $\mathrm{pH}$ continued to decrease until the last measurement, while it increased from 24 to $72 \mathrm{~h}$ after the glyphosate addition for $\mathrm{MnCO}_{3}$ (Fig. 1a, b). As a general trend, the electrical conductivity and $\mathrm{pH}$ were inversely proportional. It is worth mentioning that both $\mathrm{MnSO}_{4}$ and $\mathrm{Mn}$-glycine presented a white precipitate after mixing with glyphosate, while $\mathrm{MnCO}_{3}$ precipitated regardless glyphosate addition, since it is a low solubility source.

Following dissolution in water, $\mathrm{MnSO}_{4(\mathrm{aq})}$ forms an outer-sphere complex $\left[\mathrm{Mn}\left(\mathrm{H}_{2} \mathrm{O}\right)_{6}\right]^{2+} \mathrm{SO}_{4}{ }^{2-}[12]$, while the solubility product constant $\left(\mathrm{K}_{\mathrm{sp}}\right)$ for $\mathrm{Mn}$-glyphosate solution buffered at $\mathrm{pH} 7$ is $0.955 \times 10^{-6}$ [20]. The reduction in $\mathrm{pH}$ followed by the EC increasing is likely related to the correlation between conductivity and availability of $\mathrm{H}^{+}$ ions in solution. The $\mathrm{pH}$ decreased more intensively for $\mathrm{MnSO}_{4}$ (from 4.6 to 2.6) and Mn-glycine (from 5.5 to 3.0). This was probably due to the deprotonation of glyphosate molecules, i.e. providing $\mathrm{H}^{+}$ions to the solution, which also released adsorption sites for $\mathrm{Mn}^{2+}$ complexation.

Chahal et al. [21] also investigated the influence of glyphosate addition to a Mn solution using a commercial source based on $\mathrm{MnSO}_{4}$ (Nutrisol $8 \% \mathrm{Mn}$, Coastal AgroBusiness). The concentrations were ca. $0.8 \mathrm{~g} \mathrm{~L}^{-1}$ of $\mathrm{Mn}$ and $6.7 \mathrm{~g} \mathrm{~L}^{-1}$ of glyphosate. Differently from our data, they found an initial $\mathrm{pH}$ of 3 for the $\mathrm{Mn}$ solution, which is more acid than ours, and glyphosate raised the $\mathrm{pH}$ to 4.2 right after its addition, then remained steady until the $72 \mathrm{~h}$ elapsed. Conversely to our observations, these authors did not observe any precipitate formation.

The $\mathrm{pH}$ of the tank mixtures is considering an important parameter to assure the efficiency of the involved compounds. Machado et al. [22] reported severe epidermal cell shrinking due to the application of very acid $\mathrm{Mn}$ solutions (pH 1.4) on soybeans leaves, but further studies are still necessary to unravel the effects of the solution $\mathrm{pH}$ on foliar 




Fig. 1 Electric conductivity (a) and pH (b) of Mn aqueous solutions/ dispersion as function of time after glyphosate mixture. The data shows that glyphosate increased the electric conductivity (EC) of

fertilization efficiency. On the other hand, the influence of the $\mathrm{pH}$ on glyphosate's efficiency was better investigated. Previous studies had demonstrated that glyphosate's activity is higher in acidic $\mathrm{pH}$ than that in alkaline [23-25]. Shea and Tupy [23] observed that the increase of the glyphosate solution $\mathrm{pH}$ from 4 to 5.5 was sufficient to reduce its efficiency on weed control, but no significant difference was resultant due to the adjustment of the $\mathrm{pH}$ from 5.5 to 6 or 10 .

\subsection{Mn fractionation}

Values above the LOQ $\left(4.6 \times 10^{-7}, 5.8 \times 10^{-7}\right.$, and $4.2 \times 10^{-7} \mathrm{~mol}$ for $\mathrm{Mn}, \mathrm{P}$ and $\mathrm{S}$, respectively) were considered to determine the $\mathrm{Mn}, \mathrm{P}$ and $\mathrm{S}$ content in the obtained fractions (solutions, dispersions, supernatants, and precipitates). For $\mathrm{MnSO}_{4(\mathrm{aq})}$ (Fig. 2a) and Mn-glycine ${ }_{(\mathrm{aq})}$ (Fig. 2c) without glyphosate, no significant changes were observed for $\mathrm{pH}, \mathrm{EC}, \mathrm{Mn}$ and $\mathrm{S}$ content before and after the centrifugation process.

Most of the $\mathrm{Mn}$ and $\mathrm{P}$ provided by the mixture of $\mathrm{MnSO}_{4(\mathrm{aq})}$ and glyphosate remained in solution (Table S1), however, nearly $29 \%$ of the Mn precipitated along with ca. $28 \%$ of the P. A ca. 2:1 Mn:P molar ratio was found in the $\mathrm{MnSO}_{4}$ precipitate (Table S2). Regarding the $\mathrm{Mn}$-glycine, one should expect that the $\mathrm{Mn}$ complexation by glycine could ward off some interactions with glyphosate; however, the addition of glyphosate to the Mn-glycine solution caused the precipitation of $c a .43 \%$ of the employed $\mathrm{Mn}$, forming a precipitate with a Mn:P molar ratio of $c a .3: 1$ (Table S2), indicating that the stability constant of glyphosate is higher than that of glycine.

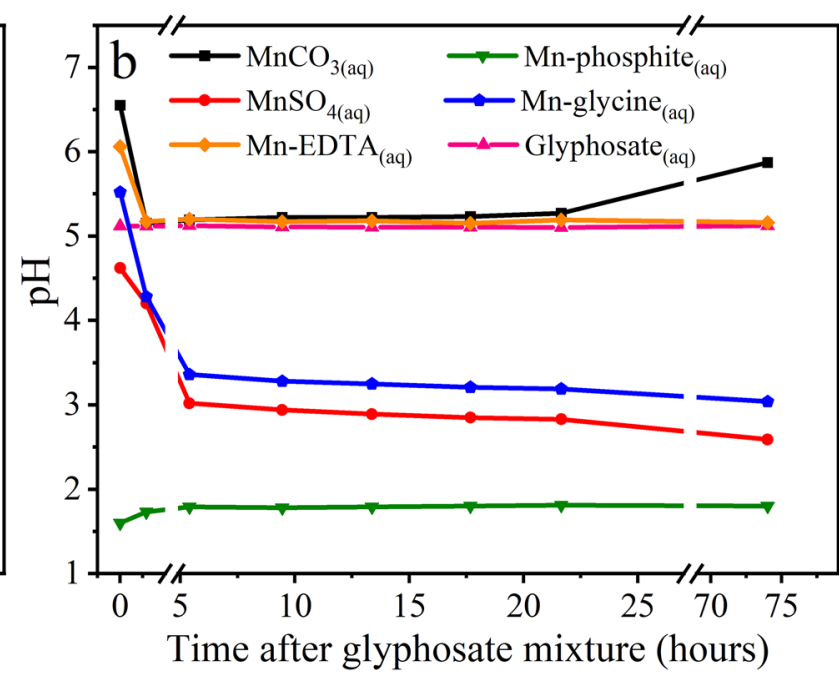

the solutions/dispersion, except for $\mathrm{Mn}$-phosphite. On the other hand, the dispersion/solutions' pH decreased with the glyphosate addition, except for $\mathrm{Mn}$-phosphite

The addition of glyphosate in both sulfur-containing sources $\left(\mathrm{MnSO}_{4}\right.$ and $\mathrm{Mn}$-glycine) did not change the $\mathrm{S}$ content in the solution, revealing that the $\mathrm{SO}_{4}{ }^{2-}$ does not precipitate along with glyphosate molecules (Fig. 2b, d). It is valuable to emphasize that glycine $\left(\mathrm{C}_{2} \mathrm{H}_{5} \mathrm{NO}_{2}\right)$ does not contain sulfur, even though this element was detected in the mixture. It suggests that the Mn-glycine fertilizer was prepared through an attempt to complex $\mathrm{Mn}^{2+}$ with glycine displacing the $\mathrm{SO}_{4}{ }^{2-}$, not completely purified.

The precipitation suggests that both $\mathrm{MnSO}_{4}$ and $\mathrm{Mn}$-glycine can lose efficiency on foliar fertilization. Thereon, minimal research is available about $\mathrm{Mn}$-glycine as fertilizer. However, the $\mathrm{MnSO}_{4}$ performance appeared negatively affected by tank mixtures with glyphosate [22]. Likewise, the herbicidal action of glyphosate may also be affected due to precipitation. Bernards et al. [12], by tracing the glyphosate movement within Abutilon theophrasti leaves (velvetleaf) using ${ }^{14} \mathrm{C}$ radiolabeled glyphosate, verified that the absorption of glyphosate by the plant was reduced in the presence of $\mathrm{Mn}$-ethylaminoacetate (Mn:glyphosate ca. 5:1), Mn-lignin sulfonate (Mn:glyphosate ca. 6:1), and $\mathrm{MnSO}_{4}$ (Mn:glyphosate ca. 25:1), while Mn-EDTA (Mn:glyphosate ca. 7:1) was the least likely to diminish glyphosate absorption, translocation and efficacy.

Mn-EDTA ${ }_{(\text {aq) }}$ presented stable $\mathrm{Mn}$ and $\mathrm{P}$ contents before and after the centrifugation, regardless of the glyphosate mixture. Although the glyphosate changed the $\mathrm{pH}$ and EC of the Mn-EDTA solution, no precipitate was formed. The $\mathrm{Mn}^{2+}$ stability constant of EDTA, $\log K=13.81$, being much 



$*_{\mathrm{mS} \mathrm{cm}}{ }^{-1}$ 
4Fig. 2 Fractions formed by Mn-containing fertilizers before and after mixing with glyphosate, with their respective $\mathrm{Mn}, \mathrm{P}$ and $\mathrm{S}$ content (when present). $\mathrm{MnSO}_{4}$ (a); $\mathrm{MnSO}_{4}+$ glyphosate (b); $\mathrm{Mn}$-glycine (c); $\mathrm{Mn}$-glycine + glyphosate (d); $\mathrm{MnCO}_{3}(\mathbf{e}) ; \mathrm{MnCO}_{3}+$ glyphosate (f); Mn-EDTA (g); Mn-EDTA + glyphosate (h); Mn-phosphite (i); $\mathrm{Mn}$-phosphite + glyphosate (j). Only values above LOQ $\left(4.6 \times 10^{-7}\right.$, $5.8 \times 10^{-7}$, and $4.2 \times 10^{-7} \mathrm{~mol}$ for $\mathrm{Mn}, \mathrm{P}$ and $\mathrm{S}$, respectively) were considered

higher than that of glyphosate, $\log K=5.53,[26]$ prevents Mn complexing with glyphosate (Fig. 2h).

Several studies highlighted that Mn-EDTA did not antagonize glyphosate efficacy $[11,12,27]$, on the contrary, it can even increase its herbicidal action $[12,27]$. The EDTA can chelate the cations present in tap water, normally used to prepare spray mixture, hence it prevents the formation of metal-glyphosate complexes. From the plant nutrition standing point, the use of in vivo X-ray spectrometry revealed that $\mathrm{Mn}$ foliar absorption and transport kinetics were not affected by the mixture of Mn-EDTA with glyphosate as well [22].

The $\mathrm{MnCO}_{3}(80-100 \mathrm{~nm})$ precipitated regardless of glyphosate addition (Fig. 2e, f). The Mn content remaining in the supernatant was lower than the established limit of quantification. When glyphosate was added ca. $23 \%$ of the total $\mathrm{P}$ precipitated with $81 \%$ of the total $\mathrm{Mn}$ applied (Table S2). EC and pH increased after the centrifugation of the $\mathrm{MnCO}_{3}$ dispersion (Fig. 2e). Then, when glyphosate was added up, the $\mathrm{pH}$ decreased while the EC increased. After centrifugation, the $\mathrm{pH}$ raised back to a value near to the one observed in the absence of glyphosate, while the EC increased only $0.2 \mathrm{mS} \mathrm{cm}^{-1}$ (Fig. 2f).

Based on the behavior of the $\mathrm{MnCO}_{3}$ dispersion, one can notice that the $\mathrm{MnCO}_{3}$ source employed in this study showed itself as an inadequate source for foliar fertilization, regardless of glyphosate mixture. Since it precipitated in its entirely, no $\mathrm{Mn}$ remained available in solution for foliar uptake. Accordingly to this statement, Migliavacca [28] found that foliar application of $\mathrm{MnCO}_{3}$ did not circumvent $\mathrm{Mn}$ deficiency in soybean plants. Likewise, Machado et al. [22] found that $\mathrm{MnCO}_{3}$ was not able to increase the $\mathrm{Mn}$ content in soybean petioles $48 \mathrm{~h}$ after leaf spraying, regardless of glyphosate mixture.

Regarding to the $\mathrm{Mn}$-phosphite $(\mathrm{aq)}$ solution, the addition of glyphosate slightly increased the $\mathrm{pH}$ and decreased the EC. This is related to the acidic behavior of phosphite compounds. Besides, $\mathrm{Mn}$-phosphite also presents high $\mathrm{P}$ content ( $\mathrm{P}$ concentration ca. fourfold higher than $\mathrm{Mn}$ ). Therefore, $\mathrm{P}$ content was not significantly changed by the glyphosate mixture. It was not observed any formation of precipitates after the addition of glyphosate to the $\mathrm{Mn}$ phosphite $_{(\mathrm{aq})}$ solution, since at such low pH (ca. 1.7), the glyphosate molecules remain protonated that ultimately provide few $\mathrm{Mn}^{2+}$ adsorption sites.
Considering the absence of visual interactions, such as precipitate formation, one should expect none negative consequences on the mixture between glyphosate and $\mathrm{Mn}$-phosphite $(\mathrm{aq})$. However, attention must be paid regarding the $\mathrm{pH}$ of the solution. Actually, on the one hand, such acid pH should not disturb glyphosate efficacy on weed control, once its activity increases as $\mathrm{pH}$ decreases [23]. On the other hand, it can be harmful to the main crop. Machado et al. [22] showed that Mn-phosphite solutions, with and without glyphosate ( $\mathrm{pH} 1.8$ and 1.6, respectively), caused severe epidermal cell shrinking on soybean leaves. Additionally, it was also shown that glyphosate reduces the $\mathrm{Mn}$ leaf uptake from $\mathrm{Mn}$-phosphite.

Among other factors, impairment of micronutrient root to shoot transport was also reported due to glyphosate, though the mechanisms behind were not elucidated. Thus, it has been demonstrated that foliar applied glyphosate can be translocated and further exudate by roots [29], potentially precipitating $\mathrm{Mn}$ in soil or nutrient solution. Moreover, Duke et al. [30] listed several studies showing no restriction of micronutrients availability for GR crops treated with glyphosate.

\subsection{Chemical speciation}

Figure 3a presents the spectra for pristine Mn fertilizers and nanopowder without glyphosate, while (b) shows the spectra for the supernatants obtained after glyphosate addition and centrifugation, and (c) the spectra for recovered precipitates. The pristine solutions of $\mathrm{Mn}$-glycine, $\mathrm{MnSO}_{4}$ and $\mathrm{Mn}$-phosphite present similar spectra, while $\mathrm{Mn}-\mathrm{EDTA}$ and $\mathrm{MnCO}_{3}$ demonstrate features that clearly differentiate them from the others.

Although the stoichiometry let appearing that part of the glyphosate remained in liquid phase, the spectra for the supernatants did not present remarkable spectral changes to support a glyphosate reaction with $\mathrm{Mn}^{2+}$ that would yield an inner-sphere Mn-glyphosate complex (Figure S4). This would be consistent with electronic paramagnetic resonance (EPR) measurements of $\mathrm{Mn}^{2+}+$ glyphosate performed by Bernards et al. [12] in a similar pH condition. On the other hand, likewise in Fig. 3b, these overlapped spectra clearly show similarities between the chemical environment of the suspended $\mathrm{Mn}$-glycine, $\mathrm{MnSO}_{4}$ and Mn-phosphite.

Machado et al. [22] obtained the Mn chemical speciation in the petioles of soybean plants which were foliar fertilized with $\mathrm{MnSO}_{4}, \mathrm{Mn}$-EDTA and $\mathrm{Mn}$-phosphite, mixed or not with glyphosate. The acquired Mn XANES spectra found no $\mathrm{Mn}$-glyphosate complexes inside the plants regardless of the applied $\mathrm{Mn}$ source. While $\mathrm{MnSO}_{4}$ and $\mathrm{Mn}$-phosphite provided $\mathrm{Mn}$ for plants in a similar chemical 


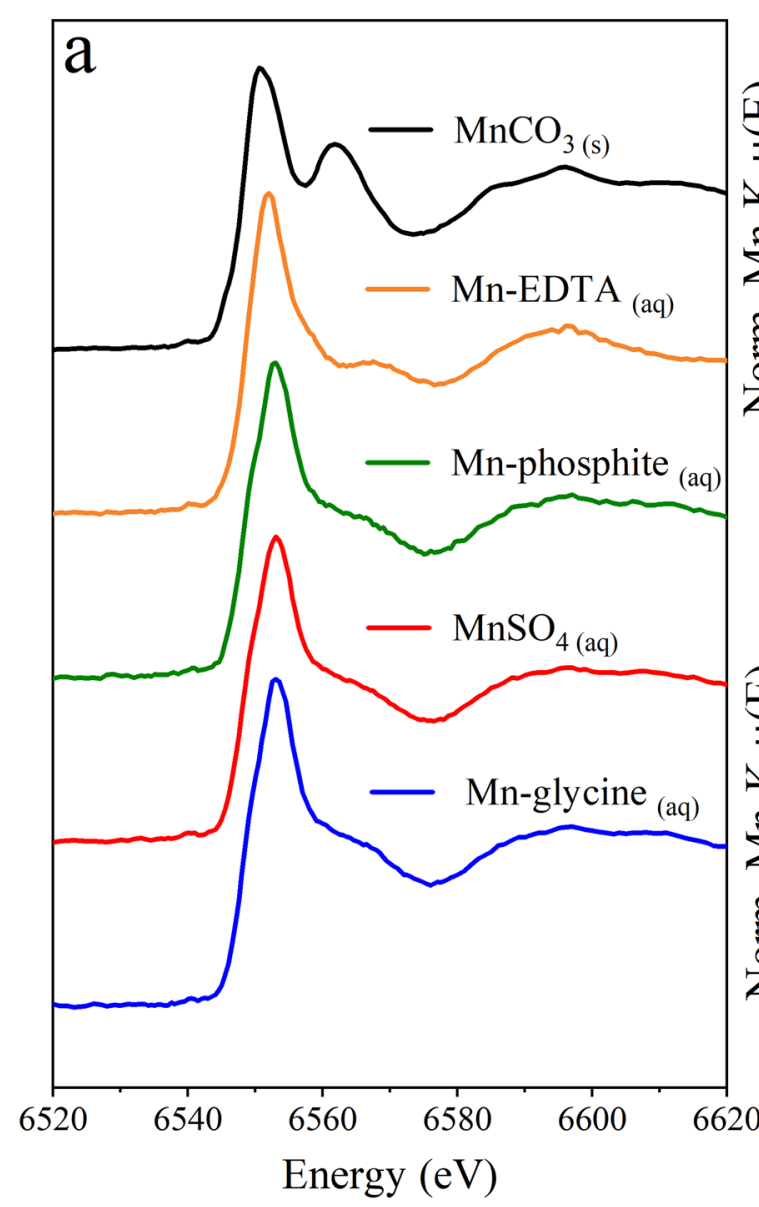

Fig. 3 XANES spectra for the Mn sources in aqueous solution and solid $\mathrm{MnCO}_{3}$ (a), liquid phase (supernatant) (b) and solid phase (precipitated) (c) obtained after mixing glyphosate to the $\mathrm{Mn}$

environment, the Mn-EDTA was still found in its pristine form, showing that the bonding force between $\mathrm{Mn}$ and EDTA is powerful enough to keep the Mn chelated all over the way from the leaf to the petiole.

Despite the reactions between aqueous $\mathrm{Mn}^{2+}$ and glyphosate within tank mixtures, the above-mentioned results [22] show that $\mathrm{Mn}$ remaining in solution is being absorbed and transported in a non-complexed form. These data, together with Bernards et al. [12], also support the rejection of the soluble complexes formation hypothesis, since they indicate that glyphosate does not interfere with the Mn chemical environment inside the plants, and that both $\mathrm{Mn}$ and glyphosate remaining in solution can accomplish their physiological impacts. It seems that the major cause for the loss of efficiency observed when $\mathrm{Mn}^{2+}$ and glyphosate are mixed, is due to the relative amount of both species available in solution.

The $\mathrm{MnSO}_{4}$ and $\mathrm{Mn}$-glycine formed similar precipitated products with glyphosate (Fig. 3c). Their spectra presented a slightly reduction of whiteline intensity compared to

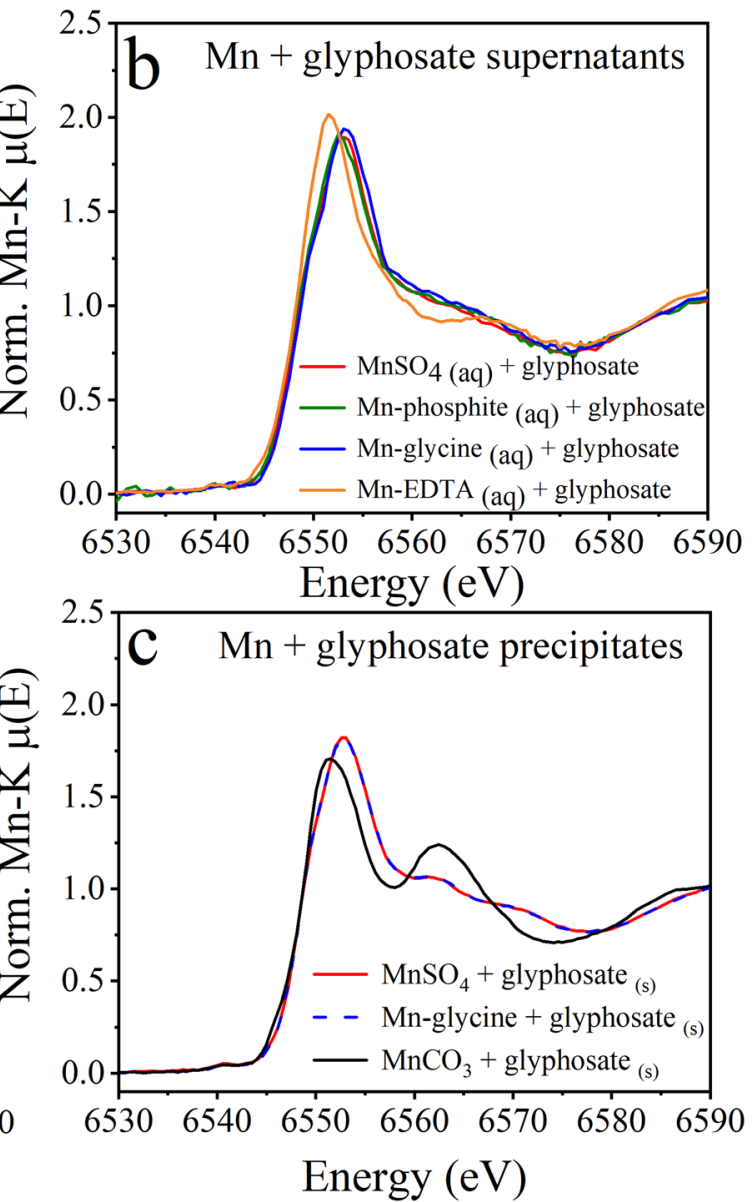

sources. Data shows that the Mn chemical environment of the liquid phase after glyphosate mixture are different, however, it is the same for the precipitates coming from $\mathrm{Mn}$-glycine and $\mathrm{MnSO}_{4}$

the pristine and supernatant forms (see also Figure S4). The reduction of whiteline intensity is associated to the increase of electron density on $p$ unoccupied states of $\mathrm{Mn}^{2+}$ ions, while edge shifts towards lower energies can be caused by increase of $\mathrm{Mn}$-ligand bond length [31]. This corroborates the chemical affinity between $\mathrm{Mn}$-glyphosate which yields a more stable molecule than $\mathrm{MnSO}_{4}$ and Mn-glycine.

As previously reported, glyphosate can form low soluble complexes with $\mathrm{Ca}^{2+}$ which cannot be absorbed by the plants leaves [32]. The $\mathrm{MnSO}_{4}+$ glyphosate precipitate presenting clear spectral differences with soluble $\mathrm{Mn}$ (Figure S4) support that such changes in the Mn chemical environment may also make the $\mathrm{Mn}$-glyphosate complexes unavailable for plant uptake. This precipitates formation is a serious practical problem, since the formed particles can clog the sprayer nozzles during field application, which compromises the operation efficiency.

Figure 4 shows the XANES spectra recorded for $\mathrm{Mn}$-glyphosate precipitate, $\mathrm{Mn}_{3}\left(\mathrm{PO}_{4}\right)_{2(\mathrm{~s})}, \mathrm{Mn}$-malate $(\mathrm{aq})$

\section{SN Applied Sciences}






Fig. 4 XANES spectra recorded for Mn-phosphate(s), Mnmalate $_{(a q)}, M_{n}$-citrate $(a q)$ and two $M n$-glyphosate precipitates, one obtained from $\mathrm{MnSO}_{4}+$ glyphosate and the other from $\mathrm{Mn}$-glycine + Glyphosate. Both Mn-glyphosate precipitates formed the same compound, which is different from $\mathrm{Mn}$-phosphate, $\mathrm{Mn}$ malate $_{(\mathrm{aq})}$ and $\mathrm{Mn}$-citrate $(\mathrm{aq})$. In aqueous solution, $\mathrm{Mn}$-malate and $\mathrm{Mn}$-citrate present a similar spectrum between them, while $\mathrm{Mn}$ phosphate differs from all the overlapped spectra in this image

and $\mathrm{Mn}$ - citrate $_{(\mathrm{aq})}$. The XANES spectra are highly affected by symmetry and oxidation state. Although the precipitate retains $\mathrm{Mn}^{2+}$, its structure is much closer to carboxyl complexed $\mathrm{Mn}^{2+}$ ( $\mathrm{Mn}$-malate and $\mathrm{Mn}$-citrate) than $\mathrm{Mn}_{3}\left(\mathrm{PO}_{4}\right)_{2(s)}$. Subramaniam and Hoggard [33] prepared non-soluble glyphosate complexes with $\mathrm{Cu}, \mathrm{Ni}$, and $\mathrm{Fe}$. The crystalline nature of the formed compounds was solved by X-ray diffraction. Infrared Fourier transform evidenced bulk glyphosate and solid complexes changes on several bands which, in principle, would suggest that amine, carboxyl and phosphonate groups participate of $\mathrm{Mn}^{2+}$ binding.

Nowack and Stone [34] reported that $\mathrm{Mn}^{2+}$ quickly decomposed nitrilotris(methylene)phosphonic acid releasing orthophosphate ions, imino(dimethylene) phosphonic acid, and $\mathrm{N}$-formylimino-(dimethylene) phosphonic acid. Conversely, Barrett and McBride [35] reported that $\mathrm{Mn}^{3+}$ cleavage on glyphosate produced glycine and orthophosphate, while this did not happen for $\mathrm{Mn}^{2+}$ at 1:1 Mn:glyphosate ratio. Otherwise, increasing $\mathrm{Mn}^{2+}$ :glyphosate proportion to 4:1 lead to a breakdown of glyphosate molecules. The present survey employed a 2:1 Mn:glyphosate molar ratio. Even if the orthophosphate had not been determined in solution, the XANES spectra recorded for the precipitates (Fig. 4) do not suggest formation of $\mathrm{Mn}_{3}\left(\mathrm{PO}_{4}\right)_{2}$ which would have happened case the glyphosate would have been decomposed by $\mathrm{Mn}^{2+}$.

Barrett and McBride [35] reported that less than $1 \%$ of $\mathrm{Mn}^{2+}$ should be complexed to glyphosate at $\mathrm{pH} 5$ and it should increase to $c a .10 \%$ at $\mathrm{pH}$ 7. They estimate these figures based on Motekaitis and Martel [36]. Incidentally,

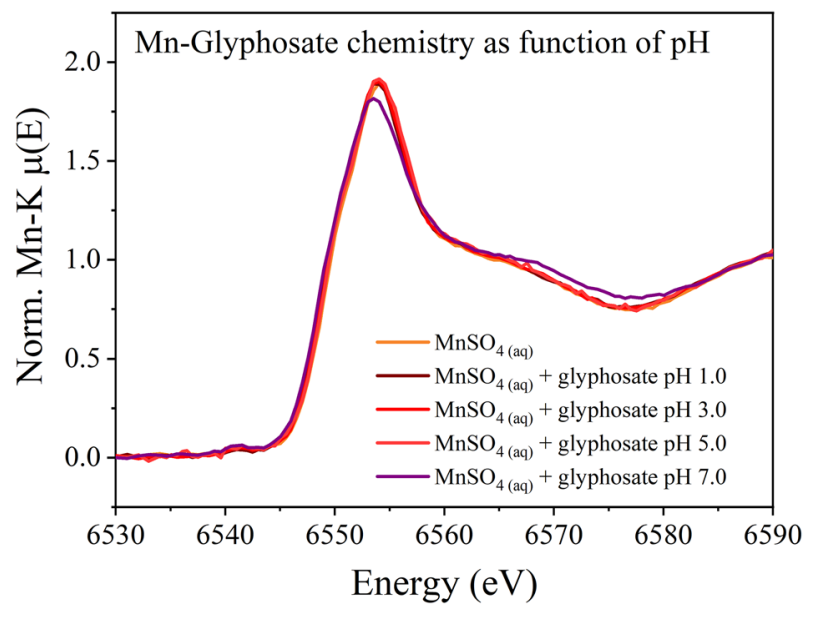

Fig. 5 XANES spectra recorded from $\mathrm{MnSO}_{4(\mathrm{aq})}+$ glyphosate supernatants at $\mathrm{pH}$ ranging from 1 to 7 . Data show different spectral features only at the $\mathrm{pH} 7$, while the other $\mathrm{pH}$ conditions offer the same one Mn chemical environment

our experiments showed that ca. $29 \%$ of $\mathrm{Mn}^{2+}$ precipitate at $\mathrm{pH}$ 2.5. A possible explanation for the deviation from theory observed in our study might be related to the concentration of ligands and $\mathrm{Mn}^{2+}$. Since our study mimicked a field application tank mixture, the concentration of reactive chemical species, i.e. $\mathrm{Mn}^{2+}$ and glyphosate, was nearly 60 -fold higher than that employed by Motekaitis and Martel [36].

\subsection{Mn-glyphosate chemistry as function of $\mathrm{pH}$}

Among the fertilizers tested in this study, manganese sulphate is the most common, cheap and glyphosate-reactive source of $\mathrm{Mn}$. Therefore, the chemistry of $\mathrm{MnSO}_{4}+$ glyphosate solutions as function of $\mathrm{pH}$ prevailed.

Glyphosate has four pKa values: $<2,2.6,5.6$, and 10.6 [37]. From pH 3-5 both carboxyl and phosphite groups are ionized. In such condition, an equilibrium between aqueous and precipitate $\mathrm{Mn}$ was observed. Precipitation immediately occurred for samples at $\mathrm{pH} 3$ and 5 , and to a larger extent at pH 5. At pH 7, glyphosate net charge was 2- and negligible brownish precipitate was found. Zeta potential values for samples at $\mathrm{pH} 2.5,5$ and 7 were close to neutrality, which means the suspended particles were within the micrometric size range (Table S3). The hydrodynamic diameter and zeta potential decreased as the $\mathrm{pH}$ increased.

Figure 5 shows the XANES spectra recorded for liquid phase after centrifugation of $\mathrm{MnSO}_{4}$-glyphosate mixture. The non-normalized XANES spectra for the $\mathrm{MnSO}_{4}+$ glyphosate solutions in ranging $\mathrm{pH}$ can be found in the supporting information (Figure S5). Under $\mathrm{pH} 1-5$, the $\mathrm{Mn}^{2+}$ remains in the same structure; only a 
slight whiteline intensity reduction was observed for $\mathrm{pH}$ 7. These outputs are in agreement with Bernards et al. [12] who outlined identical EPR spectra for $\mathrm{MnSO}_{4(\mathrm{aq})}$ and $\mathrm{MnSO}_{4(\mathrm{aq})}+$ glyphosate in $\mathrm{pH}$ range of 2.8-4.5. Under $\mathrm{pH}$ 6-7.5 they reported reduction on EPR signal amplitude which would be associated with the displacement of water and coordination by the glyphosate. The values of attenuation coefficient (Figure S5) that reflects the concentration of $\mathrm{Mn}$ in solution, are consistent with the observed precipitation yield in Figure 56 , i.e. most of the $\mathrm{Mn}$-glyphosate precipitated at $\mathrm{pH}=5$. The brownish suspended particles were not detected by XANES since they were precipitated during the centrifugation.

No $\mathrm{Mn}^{2+}$ redox state change appeared in the XANES spectrum recorded for the supernatant in $\mathrm{pH} 7$. However, a significant weight loss between 350 and $400{ }^{\circ} \mathrm{C}$ was noted in the thermogravimentric analysis (Figure S7) which indicates the occurrence of dihydroxylation and the loss of $\mathrm{SO}_{4}$ between ca. 730 and $1060^{\circ} \mathrm{C}$. This is consistent with Figueira et al. [38] that reported $10 \mathrm{wt} . \%$ weight loss between 350 and $400{ }^{\circ} \mathrm{C}$ for manganite $(\gamma-\mathrm{MnOOH})$, with an endothermic peak around $370^{\circ} \mathrm{C}$ related to the oxidation of $\gamma-\mathrm{MnOOH}$ and $\beta-\mathrm{MnO}_{2}$ (pyrolusite) formation. Hem [39] also obtained brown or black precipitates when $\mathrm{Mn}$ solutions were adjusted to $\mathrm{pH}$ higher than 8 , due to the formation of oxides, since such $\mathrm{pH}$ and oxidation-reduction potential (Eh) conditioned the oxide-stability region. Hem [39] also states that oxidation by air may occur at $\mathrm{pH}$ conditions above 8, which decreases the concentration of dissolved $\mathrm{Mn}$ in solution. The thermogravimetric curves obtained from the precipitate at $\mathrm{pH} 7$ (Figure S8) do not assert the structure of the Mn-glyphosate as solid complex.

Before ending the discussion on glyphosate and $\mathrm{Mn}$ interactions, it is worth mentioning that there are several kinds of glyphosate formulations available. Some of them present distinct active ingredients, like isopropylamine salt of glyphosate (glyphosate-IPA) or potassium salt of glyphosate (glyphosate-K), for example. Others present the same active ingredient, but with distinct formulants employed for the product stabilization. The formulants are often composed by surfactants, diluents or adjuvants, but companies do not need to declare their composition, this information being considered confidential business [14]. The glyphosate formulation employed in this study is a glyphosate-IPA based, with 48 wt.\% of active ingredient, $36 \mathrm{wt} . \%$ of acid equivalent and $68.5 \mathrm{wt} . \%$ of formulants. The formulants are considered inert ingredients according to the products label. Recent studies found that some nondeclared formulants of glyphosate based herbicides can be even more toxic than glyphosate itself $[14,40]$. Given the unknown chemistry of the formulants, attention must be paid to the fact that different glyphosate brands may present distinct performances in tank mixtures.

\section{Conclusions}

This study demonstrates the importance of the Mn source and the solutions $\mathrm{pH}$ when preparing spray mixtures with glyphosate. Indeed, glyphosate can form low solubility complexes with free $\mathrm{Mn}^{2+}$ ions in a $\mathrm{pH}$ ranging from 2.5 to 5 . Thus, complexes were found with a Mn:glyphosate molar ratio of nearly 2:1.

A similar chemical environment was found for the precipitates retrieved from the XANES analysis, regardless of the employed $\mathrm{Mn}$ source. Further studies using the $\mathrm{X}$-ray diffraction and extended absorption fine structure shall be conducted aiming at unraveling the structure of $\mathrm{Mn}$-glyphosate solids.

Our results did not support the hypothesis of a soluble inner sphere $\mathrm{Mn}$-glyphosate complex under $\mathrm{pH}$ 1-7. For sake of clarity, it is important mentioning that due to intrinsic errors introduced during the normalization of the spectra, the XANES spectra unlikely detect a fraction of soluble complex below $5 \mathrm{wt} . \%$ of the total manganese. Hence, if present, $\mathrm{Mn}$-glyphosate soluble complexes in tank mixtures would be below ca. 5 wt.\% concentration range.

The use of chelated fertilizers, such as Mn-EDTA, or the decreasing of the $\mathrm{pH}$ of the tank mixture to values $<2.5$ are alternatives to circumvent the formation of precipitates.

Acknowledgements The authors are grateful to the Brazilian Synchrotron Light Laboratory for the beamtimes under the proposals 20180150 and 20190117, and to the support from Dr. Carlos A. Perez (XRF beamline scientist). We are also grateful to the professor F.R.P Rocha and Prof. C.R. Montes (USP-CENA) for the enriching discussions and TGA analysis, respectively. We thank Prof. L.F. Fraceto (UNESP) for DLS analysis.

Funding The authors are grateful to the São Paulo Research Foundation (FAPESP) in the framework of the Grant Nos. 2018/13401-7 and 2015/05942-0, and to the Coordenação de Aperfeiçoamento de Pessoal de Nível Superior-Brasil (CAPES)_Finance Code 001, for the financial support. R. Otto is the recipient of a research productivity fellowship from the Brazilian National Council for Scientific and Technological Development (CNPq) (Grant No. 308007/2016-6).

\section{Compliance with ethical standards}

Conflict of interest The authors declare the following competing financial interest(s): In addition to resources obtained from Government agencies, this study was partially funded by Agrivalle Brasil Industria e Comercio de Produtos Agricolas LDTA do Brasil and Stoller do Brasil LDTA trough the Fundacao de Estudos Agrarios Luiz de Queiroz. The results do not imply endorsement of or preference for any source of manganese listed by the authors. 


\section{References}

1. USDA (2020) World agricultural production. In: World Agric. Prod. https://apps.fas.usda.gov/psdonline/circulars/produ ction.pdf. Accessed 17 Aug 2020

2. Caires EF, Fonseca AF (2000) Absorção de nutrientes pela soja cultivada no sistema de plantio direto em função da calagem na superfície. Bragantia 59:213-220

3. Graham RD, Hannam RJ, Uren NC (1988) Manganese in soils and plants. Springer, Netherlands

4. Grossbard E, Atkinson D (1985) The herbicide glyphosate. Butterworths, London

5. Duke SO, Powles SB (2008) Glyphosate: a once-in-a-century herbicide. Pest Manag Sci 63:1100-1106

6. Duke SO (2018) The history and current status of glyphosate. Pest Manag Sci 74:1027-1034. https://doi.org/10.1002/ ps.4652

7. Belbin FE, Hall GJ, Jackson AB, Schanschieff FE, Archibald G, Formstone C, Dodd AN (2019) Plant circadian rhythms regulate the effectiveness of a glyphosate-based herbicide. Nat Commun. https://doi.org/10.1038/s41467-019-11709-5

8. IBAMA (2018) Boletim 2018, os 10 ingredientes ativos mais vendidos. https://www.ibama.gov.br/relatorios/quimicose-biologicos/relatorios-de-comercializacao-de-agrotoxico s\#boletinsanuais. Accessed 17 Aug 2020

9. Alcántara-de la Cruz R, de Oliveira GM, de Carvalho LB, da Silva MFGF (2020) Herbicide resistance in Brazil: status, impacts, and future challenges. In: Herbicides-current research and case studies in use. IntechOpen, p 13

10. Sfredo GJ (2008) Soja no Brasil: calagem, adubação e nutrição mineral, 1st edn. Embrapa Soja, Londrina

11. Soltani N, Shropshire C, Sikkema PH (2011) Short communication: influence of manganese on efficacy of glyphosate in glyphosate-resistant soybean. Can J Plant Sci 91:1061-1064. https://doi.org/10.4141/cjps2011-035

12. Bernards $M L$, Thelen KD, Penner $D$, Muthukumaran RB, McCracken JL (2005) Glyphosate interaction with manganese in tank mixtures and its effect on glyphosate absorption and translocation. Weed Sci 53:787-794. https://doi.org/10.1614/ ws-05-043r. 1

13. Cakmak I, Yazici A, Tutus Y, Ozturk L (2009) Glyphosate reduced seed and leaf concentrations of calcium, manganese, magnesium, and iron in non-glyphosate resistant soybean. Eur J Agron 31:114-119. https://doi.org/10.1016/j.eja.2009.07.001

14. Defarge N, Spiroux de Vendômois J, Séralini GE (2018) Toxicity of formulants and heavy metals in glyphosate-based herbicides and other pesticides. Toxicol Rep 5:156-163. https://doi. org/10.1016/j.toxrep.2017.12.025

15. Soja EMBRAPA (2013) Tecnologias de Produção de SojaRegião Central do Brasil 2014, 1st edn. Embrapa Soja, Londrina

16. de Almeida E, Duran NM, Gomes MHF, Savassa SM, da Cruz TNM, Migliavacca RA, Pereira de Carvalho HW (2019) EDXRF for elemental determination of nanoparticle-related agricultural samples. X-Ray Spectrom 48:151-161. https://doi. org/10.1002/xrs.3001

17. Kadachi AN, Al-Eshaikh MA (2012) Limits of detection in XRF spectroscopy. X-Ray Spectrom 41:350-354. https://doi. org/10.1002/xrs.2412

18. Gomes MHF, Machado B de A, Rodrigues ES, Sgarbiero Montanha G, Lanzoni Rossi M, Otto R, Scaglia Linhares F, Pereira de Carvalho HW (2019) In vivo evaluation of $Z n$ foliar uptake and transport in soybean using $\mathrm{X}$-ray absorption and fluorescence spectroscopy. J Agric Food Chem. https://doi.org/10.1021/acs. jafc.9b04977
19. Ravel B, Newville M (2005) ATHENA, ARTEMIS, HEPHAESTUS: data analysis for X-ray absorption spectroscopy using IFEFFIT. J Synchrotron Radiat 12:537-541. https://doi.org/10.1107/ S0909049505012719

20. Sundaram A, Sundaram KMS (1997) Solubility products of six metal-glyphosate complexes in water and forestry soils, and their influence on glyphosate toxicity to plants. J Environ Sci Heal Part B 32:583-598. https://doi.org/10.1080/0360123970 9373104

21. Chahal GS, Jordan DL, Burton JD, Danehower D, York AC, Eure PM, Clewis B (2012) Influence of water quality and coapplied agrochemicals on efficacy of glyphosate. Weed Technol 26:167-176. https://doi.org/10.1614/wt-d-11-00060.1

22. Machado BA, Gomes MHF, Marques JPR, Otto R, De Carvalho HWP (2019) X-ray Spectroscopy Fostering the Understanding of Foliar Uptake and Transport of Mn by Soybean (Glycine max L. Merril): kinetics, Chemical Speciation, and Effects of Glyphosate. J Agric Food Chem 67:13010-13020. https://doi. org/10.1021/acs.jafc.9b05630

23. Shea PJ, Tupy DR (1984) Reversal of cation-induced reduction in glyphosate activity by EDTA. Weed Sci 32:802-806. https:// doi.org/10.1017/s0043174500060021

24. Shilling DG, Haller WT (1989) Interactive effects of diluent $\mathrm{pH}$ and calcium content on glyphosate activity on Panicum repens L. (torpedograss). Weed Res 29:441-448. https://doi. org/10.1111/j.1365-3180.1989.tb01316.x

25. Buhler DD, Burnside OC (1983) Effect of water quality, carrier volume, and acid on glyphosate phytotoxicity. Weed Sci 31:163-169

26. Madsen HEL, Christensen HH, Gottlieb-Petersen C, Andresen AF, Smidsrød O, Pontchour C-O, Phavanantha P, Pramatus S, Cyvin BN, Cyvin SJ (1978) Stability constants of copper(II), zinc, manganese(II), calcium, and magnesium complexes of $\mathrm{N}$-(phosphonomethyl)glycine (glyphosate). Acta Chem Scand 32a:79-83. https://doi.org/10.3891/acta.chem.scand.32a-0079

27. Bernards ML, Thelen KD, Penner D (2005) Glyphosate efficacy is antagonized by manganese. Weed Technol 19:27-34

28. Migliavacca RA (2018) Universidade de São Paulo Escola Superior de Agricultura "Luiz de Queiroz" Absorção foliar de fontes insolúveis de manganês em soja [Glycine max (L.) Merrill] Piracicaba 2018. University of São Paulo

29. Neumann G, Kohls S, Landsberg E, Stock-Oliveira Souza K, Yamada T, Römheld V (2006) Relevance of glyphosate transfer to non-target plants via the rhizosphere. J Plant Dis Proctect 963-969

30. Duke SO, Lydon J, Koskinen WC, Moorman TB, Chaney RL, Hammerschmidt R (2012) Glyphosate effects on plant mineral nutrition, crop rhizosphere microbiota, and plant disease in glyphosate-resistant crops. J Agric Food Chem 60:1037510397. https://doi.org/10.1021/jf302436u

31. Traulsen ML, de Carvalho HWP, Zielke P, Grunwaldt J-D (2017) The effect of electrical polarization on electronic structure in LSM electrodes: an Operando XAS, RIXS and XES Study. J Electrochem Soc 164:F3064-F3072. https://doi. org/10.1149/2.0091710jes

32. Hall GJ, Hart CA, Jones CA (2000) Plants as sources of cations antagonistic to glyphosate activity. Pest Manag Sci 56:351-358. https://doi.org/10.1002/(SICI)1526-4998(20000 4) $56: 4 \% 3 c 351: A I D-P S 151 \% 3 e 3.0 . C O ; 2-A$

33. Subramaniam V, Hoggard PE (1988) Metal complexes of glyphosate. J Agric Food Chem 36:1326-1329. https://doi. org/10.1021/jf00084a050

34. Nowack B, Stone AT (2000) Degradation of nitrilotris(methylenephosphonic acid) and related (amino) phosphonate chelating agents in the presence of manganese 
and molecular oxygen. Environ Sci Technol 34:4759-4765. https://doi.org/10.1021/es0000908

35. Barrett KA, McBride MB (2005) Oxidative degradation of glyphosate and aminomethylphosphonate by manganese oxide. Environ Sci Technol 39:9223-9228. https://doi.org/10.1021/es051 $342 d$

36. Motekaitis RJ, Martell AE (1985) Metal chelate formation by n-phosphonomethylglycine and related ligands. J Coord Chem 14:139-149. https://doi.org/10.1080/00958978508073900

37. Sprankle P, Meggitt WF, Penner D (1975) Adsorption, mobility, and microbial degradation of glyphosate in the soil. Weed Science 23:229-234

38. Figueira BAM, Angélica RS, Scheller T (2008) Síntese e caracterização de óxido hidróxido de manganês do tipo manganita (ү-MnOOH). Cerâmica 54:193-197. https://doi.org/10.1590/ s0366-69132008000200009
39. Hem JD (1963) Chemical equilibria and rates of manganese oxidation-chemistry of manganese in natural water. United States Department of the Interior, Washington, DC

40. Vanlaeys A, Dubuisson F, Seralini GE, Travert C (2018) Formulants of glyphosate-based herbicides have more deleterious impact than glyphosate on TM4 Sertoli cells. Toxicol Vitr 52:14-22. https ://doi.org/10.1016/j.tiv.2018.01.002

Publisher's Note Springer Nature remains neutral with regard to jurisdictional claims in published maps and institutional affiliations. 